\title{
The King Unas after his Death
}

\author{
Abeer Amin \\ Faculty of Tourism, Helwan University
}

\begin{abstract}
The role played by the ancient Egyptian Kings did not only confine to their lifetime. For some of them, such a role continued after their death. This is shown in the form of the post mortem veneration or deification. It reflects the fame of those kings during lifetime as well as their important deeds ${ }^{1}$. The cults of the deified kings after their death seem to have been limited to specific sites and did not prevail all over the country. These sites were either the place of birth or the place in which the funerary complexes of the kings were erected. However, there are few exceptions. ${ }^{2}$ This article deals with the documents showing the veneration of the king Unas after his death.
\end{abstract}

Keywords: Unas, Deification, Cult, Basilophoric, Middle Kingdom, Saqqara.

\section{Introduction}

Unas, the last king of the fifth Dynasty, was one of the most prominent figures that gained good fame during his life and was deified after death. Bearing in mind the fact that his daughter was married to King Teti, the founder of the sixth dynasty, it is not surprising that much attention was paid to king Unas during the sixth dynasty, a fact that appeared in six basilophores ${ }^{3}$ that were composed in Unas' cartouche during that period. ${ }^{4}$ It is believed that he was venerated during the Middle Kingdom at Saqqara and his cult was considered a local one. ${ }^{5}$ Moreover it can be noticed that three basilophores were attested in Saqqara during the Middle Kingdom as he was deified and identified with god Ptah during this period. This is confirmed by the discovery of the stela "Wnis m sA.f" which was excavated inside his complex. ${ }^{6}$ Saqqara was the place of his popularity during his life and after his death. During his reign, he built his funerary complex with its main feature, the pyramid that preserves the most complete Old Kingdom corpus, consisting of 236 spells of the Pyramid Texts. ${ }^{7}$ Moreover, after his death, two documents referring to his deification, dating back to the Middle kingdom, were found in the vicinity of his funerary complex at Saqqara.

\section{Basilophoric names after Unas:}

Evidence shows eleven composed basilophoric names after the cartouche of king Unas: Nine at Saqqara; One at Sinai; and One at Thebes. The reason for those found at Saqqara is understandable as it is known that Unas was ruling the country from Memphis, and his funerary complex was built at Saqqara. However, the basilophoric name found in Sinai was among a rock inscription, while the other one was found in Thebes in a text that refers to Ankh-Unas (anxwnis), the overseer of Upper Egypt and the commander of the army during the sixth Dynasty.

Moreover, it should be noted that eight of the composed basilophores of Unas date back to the Old Kingdom, while the remaining three ones are of the Middle Kingdom. The reason for this was due to the popularity of that king during his life and after his death in the successive dynasty because of his daughter's marriage to the new king. Moreover, he was venerated locally at Saqqara during the Middle Kingdom. The private names composed after Unas cartouches, as well as their titles, their dates and the place in which their monuments were found. These are given in table 1 .

Table 1

\begin{tabular}{|c|l|l|l|}
\hline Private Name & Owners' Title(s) & \multicolumn{1}{|c|}{ Date } & \multicolumn{1}{c|}{$\begin{array}{c}\text { Monument(s) and its } \\
\text { provenance. }\end{array}$} \\
\hline $1-$ anx -Wnis ${ }^{8}$ & $\begin{array}{l}\text { Vizier, overseer of } \\
\text { the tenant(s) of the } \\
\text { pyramid of Unas, }\end{array}$ & $\begin{array}{l}\text { 5th Dynasty, Old } \\
\text { Kingdom }\end{array}$ & $\begin{array}{l}\text { Mastaba of anx-Wnis near } \\
\text { the pyramid complex of } \\
\text { Unas at Saqqara. }{ }^{10}\end{array}$ \\
\hline
\end{tabular}

1 Frankfort, H. (1948), Kingship and the Gods, Chicago, Frankfort, p. 65-68.

2 Jequier, G., (1928), "Le Mastabat Faraoun”, IFAO, Fouilles a Saqqara, Cairo, p.32.

3 The basilophoric names are those including the name of the king as an element. They were called in the ancient

Egyptian language as " $r \mathrm{n}$. f $\mathrm{n} f \mathrm{r} \mathrm{n} \mathrm{Hm}$. f”" which means "His perfect name after his Majesty."

4 Schneider,Th. Lexikon der Pharaonen, p. 303.

5 Altenmuller, H. (1974),'Zur Vergottlichung des Konigs Unas im Alten Reich”, SAK 1, p.1.

6 . Moussa, A.M. (1971), “A Stela from Saqqara of a Family Devoted to the Cult of King Unis”, MDAIK 27, p. 83.

7 Allen, J.P. (2001), "Pyramid Texts", The Oxford Encyclopedia of Ancient Egypt III, Cairo, p.115.

8 Murray, M.A. (1908), Index of Names and Titles of the Old Kingdom, London, p.4. 
Abeer Amin

\begin{tabular}{|c|c|c|c|}
\hline Private Name & Owners' Title(s) & Date & $\begin{array}{c}\text { Monument(s) and its } \\
\text { provenance. }\end{array}$ \\
\hline & $\begin{array}{l}\text { overseer of Upper } \\
\text { Egypt, son of the } \\
\text { king from his (divine) } \\
\text { body, scribe, seal } \\
\text { bearer of the king of } \\
\text { Lower Egypt. }\end{array}$ & & \\
\hline 2- anx -Wnis ${ }^{11}$ & $\begin{array}{l}\text { Overseer of the } \\
\text { tenant(s), overseer of } \\
\text { Upper Egypt, }{ }^{12} \\
\text { overseer of the two } \\
\text { granaries, }{ }^{13} \text { seal } \\
\text { bearer of the king of } \\
\text { Lower Egypt, royal } \\
\text { acquaintance, lector } \\
\text { priest, overseer of the } \\
\text { army, the vizier. }\end{array}$ & $\begin{array}{l}6^{\text {th }} \text { Dynasty, } \text { Old } \\
\text { Kingdom. }\end{array}$ & $\begin{array}{l}\text { Mastaba of anx-Wnis at } \\
\text { Thebes, Khokha. }{ }^{14}\end{array}$ \\
\hline 3- anx-Wnis & Greatest of the ten. & $\begin{array}{l}6^{\text {th }} \text { Dynasty, } \text { Old } \\
\text { Kingdom. }\end{array}$ & $\begin{array}{l}\text { Rock inscription at Sinai } \\
\text { Wadi El Hammamat. }\end{array}$ \\
\hline 4- Wnis-Axi & $\begin{array}{l}\text { Overseer of the } \\
\text { department of the } \\
\text { great house, royal } \\
\text { acquaintance. }\end{array}$ & $\begin{array}{l}6^{\text {th }} \text { Dynasty, Old } \\
\text { Kingdom. }\end{array}$ & $\begin{array}{l}\text { Coffin of Wnis-Axi found } \\
\text { at Saqqara in the precinct of } \\
\text { Unas complex. }\end{array}$ \\
\hline 5-Wnis-[/si///] & Lector priest & $\begin{array}{l}6^{\text {th }} \text { Dynasty, } \text { Old } \\
\text { Kingdom. }\end{array}$ & $\begin{array}{l}\text { Block of stone found inside } \\
\text { the funerary temple of Unas } \\
\text { complex at Saqqara. }{ }^{17}\end{array}$ \\
\hline 6- s-n-Wnis & $\begin{array}{l}\text { Priest of the pyramid } \\
\text { of Unas, overseer of } \\
\text { the tenants of the } \\
\text { pyramid of Unas }\end{array}$ & $\begin{array}{l}6^{\text {th }} \text { Dynasty, } \\
\text { Kingdom. }\end{array}$ & $\begin{array}{l}\text { False door of s-n-Wnis } \\
\text { inside the tomb of xnw in } \\
\text { the same site of Unas } \\
\text { complex at Saqqara. }{ }^{18}\end{array}$ \\
\hline 7-Mn-Tbw Wnis & Unknown & $\begin{array}{l}\text { End of the Old } \\
\text { Kingdom. }\end{array}$ & $\begin{array}{l}\text { Mastaba of Ni-anx-PtH } \\
\text { near the causeway of Unas } \\
\text { complex at the site of } \\
\text { Saqqara. }{ }^{19}\end{array}$ \\
\hline 8- Ni-Wnis & Unknown & $\begin{array}{l}\text { End of the Old } \\
\text { Kingdom. }\end{array}$ & $\begin{array}{l}\text { Tomb of xnw father of Ni- } \\
\text { Wnis at Saqqara near Unas } \\
\text { complex. }{ }^{20}\end{array}$ \\
\hline 9-Wnis-m-sA(.f) & Lector priest & $\begin{array}{l}12^{\text {th }} \text { Dynasty, Middle } \\
\text { Kingdom. }\end{array}$ & $\begin{array}{l}\text { False door excavated south } \\
\text { of the causeway of Unas } \\
\text { complex at Saqqara. }^{21}\end{array}$ \\
\hline 10-Wnis-HA-iSt.f & $\begin{array}{l}\text { Overseer of the } \\
\text { commissioners of the }\end{array}$ & $\begin{array}{l}12^{\text {th }} \text { Dynasty, Middle } \\
\text { Kingdom }\end{array}$ & $\begin{array}{l}\text { Tomb of Wnis-HA-iSt.f } \\
\text { located near the pyramid }\end{array}$ \\
\hline
\end{tabular}

10 Mariette, A. (1989), Les Mastabas de l'anciene Empire, Paris, p. 405.

9 Baer, (1960), Rank and Titles in the Old Kingdom, The Structure of the Egyptian Administration in the Fifth and the Sixth Dynasties, Chicago, p.66.

11 Saleh, (1977), Three Old Kingdom Tombs at Thebes, Mainz/Rhein, Zaben, p.12-17.

12 Jones, (2000), An Index of Ancient Egyptian Titles, Epithets and Phrases of the Old Kingdom I, Oxford, p. 246 (896).

13 Ibid., p.254 (923)

14 Saleh, op.cit., p. 12-17.

15 PM VII, p.330.

16 Jèquier, (1929), Tombeaux de particuliers contemporains de Pepi II, Cairo, p. 102-103

17Altenmuller, H. (1974), "Zur Vergottlichung des Konigs Unas im Alten Reich", SAK 1, p.3.

18 PM III/2, p.625.

19 Fischer, H.G. (1996), "Egyptian Studies III, Varia Nova, New York, p. 50.

20 Altenmuller, H. (1974), ’Zur Vergottlichung des Konigs Unas im Alten Reich”, SAK 1, 1974, p.3.

21 Moussa, A.M. (1971),“A Stela from Saqqara of a Family Devoted to the Cult of King Unis”, MDAIK 27, p. 81-84 
The King Unas after his Death

\begin{tabular}{|l|l|l|l|}
\hline \multicolumn{1}{|c|}{ Private Name } & \multicolumn{1}{|c|}{ Owners' Title(s) } & \multicolumn{1}{|c|}{ Date } & \multicolumn{1}{c|}{$\begin{array}{c}\text { Monument(s) and its } \\
\text { provenance. }\end{array}$} \\
\hline & pyramid of Unas. & & $\begin{array}{l}\text { complex of Unas at the site } \\
\text { of Saqqara. }{ }^{22}\end{array}$ \\
\hline 11 -Wnis-r-gs-PtH & Unknown & $\begin{array}{l}12^{\text {th }} \text { Dynasty, Middle } \\
\text { Kingdom. }\end{array}$ & $\begin{array}{l}\text { False door of Wnis-r-gs- } \\
\text { PtH found south of } \\
\text { causeway of Unas complex } \\
\text { at Saqqara. }{ }^{23}\end{array}$ \\
\hline
\end{tabular}

\section{Documents showing the Deification of Unas during the Middle Kingdom}

To the south of the causeway of Unas complex at Saqqara, a limestone rectangular stela was excavated, the top of which was occupied by two hieroglyphic lines indicating the deification of that king. This stela dates back to the Middle Kingdom. ${ }^{24}$ The incised hieroglyphic inscriptions topmost can be read from right to left as follows:

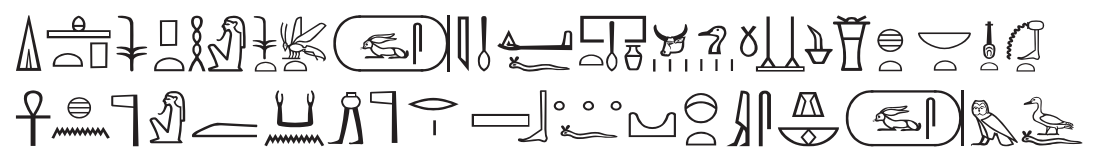

Htp di nsw PtH nswt-bity Wnis mAa-xrw di. f pr(t)-xrw (m) t Hnqt kA(w) Apd(w) Ss mnxt snTr mrHt xt nbt nfrt wabt anx nTr im n kA n innw nTr r Sbw.f Dwi psDt iit.s Xry Hbt Wnis-m-sA.f ${ }^{25}$

"An offering which the king gives (to) Ptah, and (to) the King of Upper and Lower Egypt, Unas, justified that he may give invocation-offerings (consisting of) bread, beer, oxen, fowls, alabaster, clothing, incense, ointment, every good and pure thing on which the god lives, to the ka of the one who brings the god to his food offerings, and who summons the Ennead that she comes, (namely) the lector priest, Unasemsaf'. ${ }^{26}$

Another document dating back to the Middle Kingdom depicts the cult of king Unas. It was excavated in the valley temple of his complex. It is a group of statues ${ }^{27}$ belonging to a man known as "Sermaat" (sr mAat) and his wife "Khenmet" (xnmt). The back of the statue is occupied with a text of nine hieroglyphic lines referring to Unas as a god. ${ }^{28}$ A part of the incised nine hieroglyphic lines reads as follows;

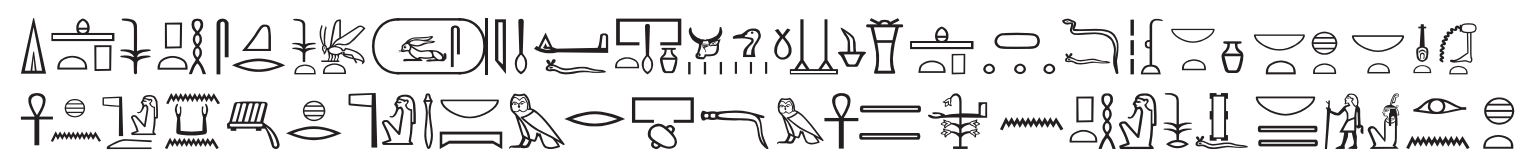

Htp di nsw PtH-Skr nswt-bity Wnis mAa-xrw di.f prt xrw (m) t Hnqt kAw Apdw Ss mnxt snTrmrHt(A) Htpt DfAw rnpit nbt Hnqt nbt xt nbt nfrt wabt anxt nTr im $n k A$ imAxi $x r n$ Tr aA nb pt imy-rA pr-Hsbit mH $m$ anx- tAwy SmAaw $n$ PtH rsy inb.f nb tAwy Sr-mAat iri $n x t i^{29}$

"A boon that the king gives to Ptah- Sokar, the king of Upper and Lower Egypt, Unas, justified, that he may give invocation-offerings (consisting of) bread, beer, oxen, fowl, alabaster, clothes, incense, ointment, all food offerings, all good and pure things on which the god lives to the ka of the one honored by the great god, the lord of the

22 Saad, Z.Y. (1940), "Preliminary Report on the Excavations at Saqqara 1939-1940", ASAE 40, P. 685.

23 Moussa, A.M. (1971), “A Stela from Saqqara of a Family Devoted to the Cult of King Unis”, MDAIK 27, p. 81-84

24 This stela was discovered by Ahmed M. Moussa on the 2nd of December 1965. It is preserved in the magazine of Saqqara, number 16110 .

25 Moussa, A.M. (1971), “A Stela from Saqqara of a Family Devoted to the Cult of King Unis”, MDAIK 27, p. 81.

26 According to A.M.Moussa the formation of the theophoric name with the adverbial predicate $\mathrm{m}-\mathrm{sA}$. $\mathrm{f}$ was frequently known in the Middle Kingdom. It is an indication that this as well as the writing of the king's name without a cartouche points to the deification of the king during the Middle Kingdom. The formation of the name is also expressed in the offering formula. For further details of the description of that stela see A.M. Moussa, "A Stela from Saqqara of a Family Devoted to the Cult of King Unis" MDAIK 27, Cairo, 1971, p. 81-83.

27 This statue was discovered on the 2nd of December 1972 by A. M. Moussa and H. Altenmüller.

28 Moussa, A.M. und Altenmüller, H. (1975), "Ein Denkmal zum Kult des Königs Unas am Ende der 12 Dynastie",

MDAIK 31, Cairo, p. 93.

29 Ibid, p. 94. 
sky, the steward of the reckoning of the Lower Egyptian, barley in Ankhtawy (anx-tAwy), the singer of Ptah south of his wall, the lord of the two lands, Sermaat (sr-mAat) ". ${ }^{30}$

Altenmüller believed that King Unas was venerated during the Middle kingdom at Saqqara and that his cult was a local one. ${ }^{31}$ Moreover, it is believed by Moussa that the invocation to Unas as "the justified" was perhaps due to the death of the king in the course of carving both of the above mentioned monuments. Furthermore, he suggested that writing the name of the king without the royal cartouche testifies that he was considered a god because he was described in Saqqara stela as the one who brings the god to his offering-food, and who summons the Ennead which will come. In this text, the god referred to is King Unas himself represented in the form of a statue. It is an indication that the cult of Unas flourished and continued until the erection of this stela. ${ }^{32}$

Buildings adjoining Unas monuments:

Unas pyramid is surrounded by a big number of monuments; most of them date back to the $5^{\text {th }}$ and $6^{\text {th }}$ Dynasties as well as to the Middle Kingdom. However, rare monuments surrounding his complex date back to the New Kingdom. Such monuments of the Middle Kingdom around Unas monument are the main concern of this study. They reflect the importance of that king after his death and his veneration as a local god in the site he chose for the building his funerary complex. This site was used during the Middle Kingdom as a cult center for Unas himself. Table 2 shows the monument of the Middle Kingdom in the vicinity of Unas complex.

Table $\mathbf{n}^{\circ} 2$

\begin{tabular}{|c|c|c|c|c|}
\hline Monument & $\begin{array}{l}\text { Owner's } \\
\text { name }\end{array}$ & Date & Owner's position & Site of \\
\hline $\begin{array}{l}\text { 1-Mastaba of } \\
\text { Wnis-HA-iStf. } \\
\text { Originally built for } \\
\text { his father Inspector } \\
\text { of prophets of the } \\
\text { pyramid of Unas. }\end{array}$ & Wnis-HA-iStf & Middle Kindom(?) & $\begin{array}{ll}\text { Overseer } & \text { of } \\
\text { commissions } & \text { of } \\
\text { the pyramid } & \text { of } \\
\text { Unas. } & \end{array}$ & $\begin{array}{l}\text { South of the } \\
\text { Causeway of the } \\
\text { complex of Unas. }\end{array}$ \\
\hline $\begin{array}{l}\text { 2- Mastaba of } \\
\text { "xnw" }\end{array}$ & Xnw & $\begin{array}{l}\text { Late } 6^{\text {th }} \text { Dynasty(?) } \\
\text { or } \\
\text { Kingdom }^{34}\end{array}$ & $\begin{array}{l}\text { Tenant of the } \\
\text { Pyramid of Unas, } \\
\text { Noble of the king } \\
\text { of the great } \\
\text { house. }\end{array}$ & $\begin{array}{l}\text { South of the } \\
\text { Causeway of the } \\
\text { complex of Unas. }\end{array}$ \\
\hline 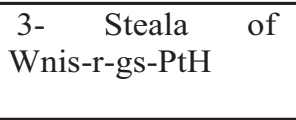 & $\begin{array}{l}\text { Wnis-r-gs-PtH } \\
35\end{array}$ & Middle Kingdom & Purifying priest & $\begin{array}{l}\text { South of the } \\
\text { Causeway of the } \\
\text { complex of Unas. }\end{array}$ \\
\hline $\begin{array}{l}\text { 4-A group of } \\
\text { statues }^{36} \text { of a man } \\
\text { known as sr mAat } \\
\text { and his wife } x n m t .\end{array}$ & $\begin{array}{l}\text { sr mAat and } \\
\text { his wife xnmt. }\end{array}$ & Middle Kingdom & $\begin{array}{l}\text { Steward of } \\
\text { reckoning of the } \\
\text { lower Egyptian } \\
\text { barley in "anx- } \\
\text { tAwy" The singer } \\
\text { of ptah south of } \\
\text { his wall. }\end{array}$ & $\begin{array}{l}\text { Inside the valley } \\
\text { temple of Unas' } \\
\text { complex }\end{array}$ \\
\hline
\end{tabular}

\section{Conclusion}

The after-death cult of the deified kings seems to have been limited to specific sites and did not prevail all over the country. These sites were either the place of birth or the place in which the funerary complexes of the kings were

30 Gaber, A. A. (2003), “Aspects of the Deification of Some Old Kings”, A Delta Man in Yebu Occasional Volume of the Egyptologists' Electronic Forum I, p. 22

31 Ibid; p. 22.

32 Moussa, A.M. (1971), “A Stela from Saqqara of a Family Devoted to the Cult of King Unis”, MDAIK 27, p. 83.

33 PM.III, p. 615-616.

34 PM. III, p. 624-625.

35 Moussa, A.M. (1971)," A Stela from Saqqara of a Family Devoted to the Cult of King Unis”, MDAIK 27, Cairo, p. 82.

36 This statue was discovered on the 2nd of December 1972 by A. M. Moussa and H. Altenmüller.

37 Gaber A.A. (2003), A Delta Man in Yebu, 1 "Aspects of the Deification of Some Old Kingdom Kings", Electronic Forum, p.22. 
constructed. ${ }^{38}$ It is suggested that priests, who were responsible for the deification of the dead kings, secured some economic advantage in exploiting the piety of the people. ${ }^{39}$

It is evident, however, that Saqqara was the main cult center of Unas after his death. Other similar cases includes: the veneration of Snefru in Sinai, Mentuhotep-Nebhepetre in Thebes and Senusert III in Nubia. Although the post mortem veneration of Unas immediately began after his death, it particularly flourished during the Middle Kingdom. However, it seems that his popularity was still important during the Ramesside and later periods as evident by the restoration of his temple by Khaemwaset. Moreover, his Horus Name wAD-tAwy was also used by Takeloth III of the $23^{\text {rd }}$ Dynasty and Philippe Arrhiadeus, the half-brother of Alexander the Great. References

Allen, J.P. (2001), "Pyramid Texts", The Oxford Encyclopedia of Ancient Egypt III, Cairo.

Allen, M.A. (1908), Index of Names and Titles of the Old Kingdom, London.

Altenmuller, H. (1974), “Zur Vergottlichung des Konigs Unas im Alten Reich”, SAK 1.

Baer, (1960), Rank and Titles in the Old Kingdom, The Structure of the Egyptian Administration in the Fifth and the Sixth Dynasties, Chicago.

Firth and Gunn, B. (1926), “Teti Pyramid Cemeteries”, vol.1, IFAO, Excavations at Saqqara, Cairo.

Fischer, H.G. (1996), “Egyptian Studies III, Varia Nova, New York.

Gaber, A. (2003), "Aspects of the Deification of Some Old Kings", A Delta Man in Yebu Occasional Volume of the Egyptologists' Electronic Forum I.

Jequier, G. (1928), “Le Mastabat Faraoun”, IFAO, Fouilles a Saqqara, Cairo.

Jèquier, (1929), Tombeaux de particuliers contemporains de Pepi II, Cairo.

Jones, (2000), An Index of Ancient Egyptian Titles, Epithets and Phrases of the Old Kingdom I, Oxford.

Mariette, A. (1989), Les Mastabas de l'anciene Empire, Paris.

Moussa, A.M. und Altenmüller, H. (1975), "Ein Denkmal zum Kult des Königs Unas am Ende der 12 Dynastie", MDAIK 31,Cairo.

Moussa, A.M. (1971)," A Stela from Saqqara of a Family Devoted to the Cult of King Unis”, MDAIK 27, Cairo.

Porter \& Moss, vol., III.

Saad, Z.Y. (1939-1940), "Preliminary Report on the Excavations at Saqqara", ASAE 40.

Saleh, (1977), Three Old Kingdom Tombs at Thebes, Mainz/Rhein, Zaben.

$$
\text { الملك أوناس بعد وفاته }
$$

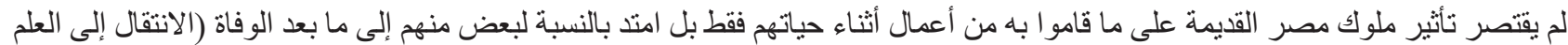

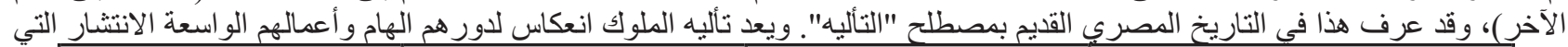

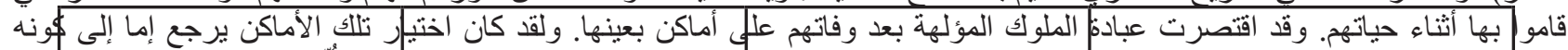

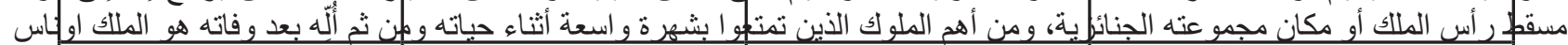

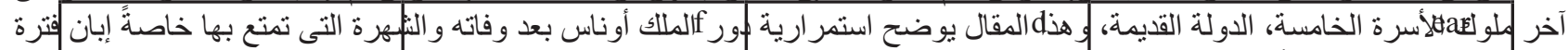
الدولة الوسطى حيث بدا تأليه هذا الملك و الخحة الخحا في تلك الأثناء.

38 Jequier, G. (1928)," Le Mastabat Faraoun”, IFAO,Fouilles a Saqqara ,Cairo, p.32.

39 Firth, C. and Gunn, B. (1926), “Teti Pyramid Cemeteries”, vol.1, IFAO, Excavations at Saqqara, Cairo, p. 223. 